\title{
Stereoacuity in preschool children - could the Randot stereotest be the screening test to prevent amblyopia?
}

\author{
Stereopsja u dzieci przedszkolnych - Test Randota jako badanie przesiewowe \\ w wykrywaniu niedowidzenia?

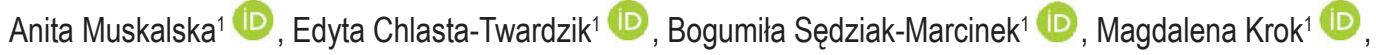 \\ Dorota Pojda-Wilczek² \\ 'Students' Scientific Society, Department of Ophthalmology, School of Medicine in Katowice, \\ Medical University of Silesia in Katowice \\ ${ }^{2}$ Department of Ophthalmology, School of Medicine in Katowice, Medical University of Silesia in Katowice
}

\begin{abstract}
INTRODUCTION: Amblyopia in the preschool age may lead to abnormal psychomotor development. It may result from binocular visual disorders (anisometropia, vision defects, strabismus, cataract, others) and leads to a lack of stereoscopic vision or to reduced stereoacuity in adulthood. Early detection of amblyopia can provide a chance for treatment to improve vision and for appropriate development of the child.

MATERIAL AND METHODS: The examination was performed using the Randot stereotest and a set of wooden blocks. 412 girls and 398 boys in the age range of 3 to 7 years were examined. In the case of a lack of stereoscopic vision, the children were referred for an ophthalmological examination. Analyses were performed using the Cochran-Armitage and Jonckheere-Terpstry tests for trend in MedCalc and SPSS 17.0 software.

RESULTS: Stereoacuity was not found in $18(2.2 \%)$ children. Most of the examined children had a stereoacuity level of 100 seconds of arc: $76 \%$ of the 3 -year-old children, $46 \%$ of the 4 -year-old children and $60 \%$ of the 5 -year-old children. Among the older children the highest percentage reached the stereoacuity level of 70 seconds of arc. The level of stereopsis increases with age statistically significantly. Binocular amblyopia caused by refractive errors was found in children in whom stereopsis was not found.

CONCLUSIONS: The Randot stereotest turned out to be an effective tool in detecting binocular vision disorders in preschool children. The authors suggest implementing the Randot stereotest to complement the screening program to detect amblyopia in preschool children.
\end{abstract}

KEY WORDS

amblyopia, Randot stereotest, stereoscopic vision, prevention, preschool children, screening, stereoacuity

\section{STRESZCZENIE}

WSTĘP: Zaburzenia rozwoju widzenia (niedowidzenie) mogą wynikać z zaburzeń refrakcji, wad wzroku, zeza, deformacji gałki ocznej lub przeszkód w ośrodkach optycznych (np. zaćma). Niedowidzenie u dzieci w wieku przedszkolnym może prowadzić do nieprawidłowości w rozwoju psychoruchowym. Jego wczesne wykrycie daje szansę na leczenie i prawidłowy rozwój dziecka.

Received: 06.12.2018 Revised: 02.06.2019 Accepted: 02.06.2019 Published online: 22.10 .2019

Address for correspondence: Anita Muskalska, Students' Scientific Society, Department of Ophthalmology, School of Medicine in Katowice, Medical University of Silesia in Katowice, ul. Ceglana 35, 40-514 Katowice, tel. + 48609739 675, e-mail: anitamuskalska@wp.pl

Copyright @ Śląski Uniwersytet Medyczny w Katowicach

www.annales.sum.edu.pl 
MATERIA I METODY: Pierwszą część badania przeprowadzono za pomocą Testu Randota. Druga część badania polegała na ułożeniu przez dzieci jak najwyższej wieży zbudowanej z drewnianych klocków. Przebadano 412 dziewczynek i 398 chłopców w wieku od 3 do 7 lat. W przypadku braku widzenia stereoskopowego dzieci zostały skierowane na badanie okulistyczne. Statystyka przeprowadzona została za pomocą testów dla trendu Cochran-Armitage i Jonckheere-Terpstry przy użyciu oprogramowania MedCalc i SPSS 17.0.

WYNIKI: U 18 (2,2\%) dzieci stereopsji nie stwierdzono. Najwięcej dzieci osiągnęło głębię widzenia na poziomie 100 sekund kątowych: 76\% 3-latków, 46\% 4-latków i 60\% 5-latków. Wśród starszych dzieci największa grupa osiągnęła poziom stereopsji na poziomie 70 sekund kątowych (43\% 6-latków i 53\% 7-latków). Wieżę z klocków prawidłowo ustawiły wszystkie dzieci (100\%). Poziom stereopsji zwiększał się z wiekiem istotnie statystycznie. U dzieci bez widzenia stereoskopowego stwierdzono niedowidzenie jedno- lub obuoczne z powodu wad refrakcji.

WNIOSKI: Test Randota okazał się skutecznym narzędziem w wykrywaniu zaburzeń widzenia obuocznego u dzieci przedszkolnych. Autorki sugerują wprowadzenie Testu Randota jako uzupełnienie badania przesiewowego w wykrywaniu niedowidzenia u dzieci przedszkolnych.

\section{SŁOWA KLUCZOWE}

dzieci 12-letnie, program zdrowotny, frekwencja próchnicy, DMFT, lakowanie zębów trzonowych

\section{INTRODUCTION}

Stereopsis is the ability to see three-dimensionally, which is found in individuals with normally developed binocular vision. For stereoscopic vision to occur, the brain constructs a single mental image of a scene based on two slightly different images received from both eyes. By measuring stereoacuity, the examiner will gain information about the level of sensory binocularity the patient has. It is known that reduced stereoacuity can be associated with vision disorders, including strabismus, amblyopia, or significant refractive errors [1]. These impairments are often found in children. Their estimated prevalence in childhood is $2-5 \%$ for amblyopia, $3-4 \%$ for strabismus, and $15-30 \%$ for significant refractive errors [2].

Amblyopia may occur as a result of binocular vision disorders like: significant refractive abnormalities, vision defects, strabismus, deformations of the eyeball or barriers in the optical media (i.e. cataract). All these visual impairments lead to a lack of stereoscopic vision or to a reduced level of stereoacuity. When found, stereoscopic vision disorders should be referred for a further ophthalmological examination to correctly determine the cause of amblyopia.

The development of stereopsis is parallel to the maturation of the visual system and the improvement of visual acuity. The crucial period for the development of those features is the preschool age. Amblyopia in the preschool age may lead to abnormal psychomotor development. Early amblyopia detection can provide a chance for treatment to improve vision, and for appropriate development of the child.

Reduced stereoacuity in children is known to affect neurodevelopmental performance, and can lead to severe lifelong consequences. It could be the reason for future professional limitations, e.g. working as a pilot, navigating an aircraft, joining the police force. It also limits sporting ability and academic performance [3].

The aim of our study is to present the stereoscopic vision examination as an easy way to detect stereoscopic, and so binocular vision disorders, which may occur as amblyopia among children in the preschool age.

\section{PATIENTS AND METHOD}

The research of stereoscopic vision was conducted in a group of 815 children aged 3-7 in 12 kindergartens in Zabrze, Poland. There were 412 girls and 398 boys, 25 (3\%) of whom had spectacle correction. The research consisted of 2 stages: stereoscopic vision examination and building a tower with wooden blocks.

The examination of stereoscopic vision was performed with the Randot stereotest. In this test, stereoacuity is measured by the seconds of arc. The highest detectable binocular depth perception is valued at 20 seconds of arc. The Randot stereotest includes: a test with two levels of stereopsis (500 and 250 seconds of arc), a graded circle test (400 to 20 seconds of arc), animal testing for young children (400 to 100 seconds of arc) and one set of stereo glasses. In the first part of the test, the examiner checks for the presence of stereoscopic vision at the levels of 500-250 seconds of arc. The further parts of the examination test the patient's depth perception up to the maximum level of 20 seconds of arc.

The test used for this study was produced by the Stereo Optical Company, Inc. Randot is a registered trademark of the Stereo Optical Company, Inc. The statistical analyses were performed with SPSS software 17.0 (Jonckheere-Terpstry test for trend) and MedCalc software (Cochran-Armitage test for trend). The stereoscopic vision measurement with the Randot stereotest was performed in a well illuminated room in daylight. To be examined, the child wore polarizing glasses. If he/she had spectacle correction, the polarizing glasses were used together with child's own glasses. The test was shown from about $40 \mathrm{~cm}$ in front of the child, perpendicular to his/her line of sight. The task was to isolate a printed figure from the background. The task was explained to the child accurately before the examination. The child was not rushed as he/she might have needed some time to closely observe the test and analyze it. The patient 
was encouraged to touch the picture (animal, circle) which seemed to be more convex, closer. In the case of a lack of stereoscopic vision only a flat image would be seen, so the child would not be able to correctly choose the right figure.

In the second part of the study wooden blocks $(5 \mathrm{~cm} /$ $5 \mathrm{~cm} / 5 \mathrm{~cm}$ ) were used. The child was asked to build a tower putting one block upon another, until the tower fell down.

\section{RESULTS}

The number of examined children is shown in Table I. There were 815 children qualified for the current study, stereoacuity examination was performed in $810(99.4 \%)$ children. Five $(0.6 \%)$ children were disqualified, as they were not able to follow the instructions. The current results are related to the number of children who completed the Randot stereotest. The majority of the examined children achieved the stereoacuity level of 100 seconds of arc: $76 \%(\mathrm{~N}=43)$ in the group aged 3, $46 \%(\mathrm{~N}=86)$ in the group aged $4,60 \%(\mathrm{~N}=186)$ in the group aged 5. Children in the age of 6 and 7 achieved better results than the younger ones. The most common result of the older children was 70 seconds of arc, found in $43 \%(\mathrm{~N}=92)$ of children aged 6 and $53 \%(\mathrm{~N}=23)$ of children aged 7 (Tab. II, Fig. 1). The presence of stereoscopic vision was found in 792 children $(97.8 \%)$, in 18 $(2.2 \%)$ children stereoscopic vision was absent (including 4 children with Down syndrome).

\begin{tabular}{|c|c|}
\hline \multicolumn{2}{|c|}{$\begin{array}{l}\text { Completion rates for Randot stereotest among } \\
\text { children who underwent vision screening }\end{array}$} \\
\hline Group & Rate of completion (\%) \\
\hline \multicolumn{2}{|l|}{ Age, y } \\
\hline $3(n=61)$ & 92 \\
\hline $4(n=186)$ & 100 \\
\hline $5(n=310)$ & 100 \\
\hline $6(n=215)$ & 100 \\
\hline $7(n=43)$ & 100 \\
\hline Total $(n=815)$ & 97.6 \\
\hline
\end{tabular}

There is a correlation between the age and the level of stereopsis. The level of stereopsis increases with age statistically significantly. The percentage of children who achieved the stereopsis level of 50 or 70 seconds of arc increases with age, the percentage of children who achieved the stereopsis level of 200, 140 or 100 seconds of arc decreases with age statistically significantly.

Children without stereoscopic vision did not have spectacle correction and they had not been examined by an ophthalmologist before. An appointment at the Department of Ophthalmology of the Medical University of Silesia in Katowice, Poland, was proposed to their parents. Only 3 of the 18 children reported for an examination at the clinic. It was found that all the examined children (100\%) have bilateral amblyopia due to refractive errors (Tab. III).

There was no correlation found between sex and the stereopsis level.

All of the examined children, regardless of the presence of stereoscopic vision, built the tower of wooden blocks correctly.

\section{DISCUSSION}

Binocular vision disorders in preschool children do not manifest in problems with playing, which was proven by the fact that all of the examined children, whether stereoscopic vision was present or not, built the tower of wooden blocks correctly. The high overall completion rate for the Randot stereotest means that the stereoacuity examination is easy to perform in preschool children, though it is not yet in common use. The Randot stereotest examination is non-invasive, easy to perform and often treated by a child as a game, so that not only an ophthalmologist can conduct it, which makes it suitable as a screening test. Amblyopia in young children is often not noticeable and usually is not obvious for parents or paediatricians. It shows the importance of early screenings in preschool children, as detecting amblyopia early enough, it is possible to provide such conditions for the visual system to let it develop properly. By conducting vision screening early enough, doctors of primary health care play a key role in saving correct vision in young children.

Available studies state that amblyopia among preschool children has incidence of $1-4 \%$ [5] or $1-5 \%$ [5].

Table II. p values calculated by Cochran-Armitage test for trend with MedCalc Software Tabela II. Wartości p obliczone za pomocą testu dla trendu Cochran-Armitage w programie MedCalc

\begin{tabular}{lcccccccccccc}
\hline age/arc sec. & $\mathbf{4 0 0}$ & $\mathbf{2 5 0}$ & $\mathbf{2 0 0}$ & $\mathbf{1 4 0}$ & $\mathbf{1 0 0}$ & $\mathbf{7 0}$ & $\mathbf{5 0}$ & $\mathbf{4 0}$ & $\mathbf{3 0}$ & $\mathbf{2 5}$ & $\mathbf{2 0}$ \\
\hline 3 & $0.030 \%$ & $0.00 \%$ & $5.00 \%$ & $2.00 \%$ & $76.00 \%$ & $11.00 \%$ & $2.00 \%$ & $4.00 \%$ & $0.00 \%$ & $0.00 \%$ & $0.00 \%$ \\
4 & $1.00 \%$ & $2.00 \%$ & $8.00 \%$ & $8.00 \%$ & $46.00 \%$ & $26.00 \%$ & $4.00 \%$ & $2.00 \%$ & $0.00 \%$ & $1.00 \%$ & $2.00 \%$ \\
5 & $0.00 \%$ & $0.00 \%$ & $1.00 \%$ & $1.00 \%$ & $59.60 \%$ & $26.16 \%$ & $4.63 \%$ & $3.00 \%$ & $1.00 \%$ & $0.50 \%$ & $3.00 \%$ \\
6 & $1.00 \%$ & $0.00 \%$ & $1.00 \%$ & $1.00 \%$ & $40.00 \%$ & $43.00 \%$ & $7.00 \%$ & $3.00 \%$ & $1.00 \%$ & $1.00 \%$ & $2.00 \%$ \\
7 & $0.00 \%$ & $0.00 \%$ & $0.00 \%$ & $0.00 \%$ & $16.00 \%$ & $53.00 \%$ & $18.00 \%$ & $5.00 \%$ & $0.00 \%$ & $5.00 \%$ & $3.00 \%$ \\
P for trend & $\mathrm{NR}$ & $\mathrm{NR}$ & $<0,0001$ & 0.0011 & $<0.0001$ & $<0.0001$ & 0.0014 & $\mathrm{NR}$ & $\mathrm{NR}$ & $\mathrm{NR}$ & $\mathrm{NR}$ \\
\hline
\end{tabular}


Table III. Results of ophthalmological examination of children with no stereopsis, performed in Ophthalmology Clinic and Department of Ophthalmology, School of Medicine in Katowice, Medical University of Silesia in Katowice, 18 Medykow Street, 40-752 Katowice, Poland Tabela III. Wyniki badania okulistycznego dzieci, przeprowadzone w Klinice Okulistyki Katedry Okulistyki Wydziału Nauk Medycznych w Katowicach, Ślaskiego Uniwersytetu Medycznego w Katowicach, u których nie wykryto widzenia stereoskopowego

\begin{tabular}{|c|c|c|c|c|}
\hline Patient & VA (visual acuity) RE (right eye) & VA (visual acuity) LE (left eye) & Refraction results & Amblyopia \\
\hline Girl age 6 & 0.6 & 0.5 & $\begin{array}{l}\mathrm{RE}=+2.0 \mathrm{D} \\
\mathrm{LE}=+3.0 \mathrm{D}\end{array}$ & both eyes \\
\hline Girl age 6, Down syndrome & 0.2 & 0.3 & $\begin{array}{l}\mathrm{RE}=+3.5 \mathrm{D} \\
\mathrm{LE}=+3.5 \mathrm{D}\end{array}$ & both eyes \\
\hline Boy age 5 & 0.25 & 0.08 & $\begin{array}{l}\mathrm{RE}=+8.0 \mathrm{D} \\
\mathrm{LE}=+10.0 \mathrm{D}\end{array}$ & both eyes \\
\hline
\end{tabular}

Uncorrected amblyopia may influence both the child's psychosocial and motor development as well as functioning in his future adult life. Packwood EA and others wrote about the psychosocial issues related to amblyopia, stating that the child's self-image, work, school and friendships are affected. Similar conclusions are found by other authors $[6,7]$.

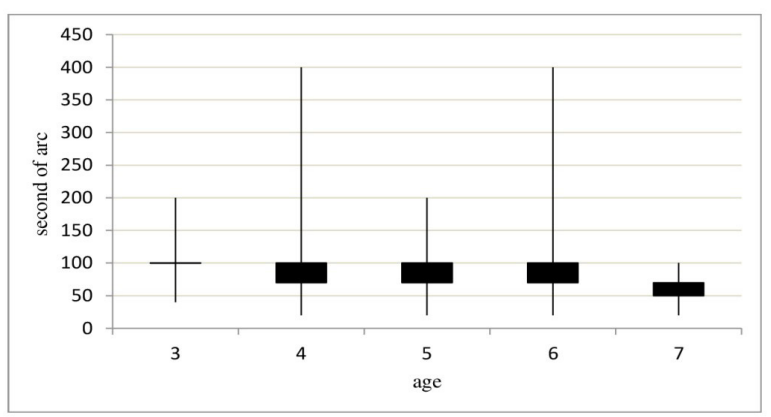

Fig. 1. By means of Jonckheere-Terpstry test using SPSS Statistics 17.0 it is shown that with age stereoacuity improves $(p<0.001)$. Figure 1 also shows medians of stereoacuity levels for each age group: 100 seconds of arc for children aged 3, 4 and 5, and 70 seconds of arc for children aged 6 and 7. Presented stereoscopic vision ranges for each age group are calculated according to first and third quartile. For children aged 3 it is 100 seconds of arc, for children aged 4, 5, 6-70-100 seconds of arc and for children aged 7-50-70 seconds of arc.

Ryc. 1. Za pomocą testu Jonckheere-Terpstry w programie SPSS Statistics 17.0 stwierdzono, że wraz z wiekiem poziom stereopsji ulega poprawie $(p<0.001)$. Rycina 1 ukazuje mediany poziomów stereopsji dla każdej z grup wiekowych: 100 sekund katowych dla dzieci w wieku 3, 4 i 5 lat i 70 sekund katowych dla dzieci w wieku 6 i 7 lat. Przedstawione zakresy widzenia stereoskopowego dla poszczególnych grup wiekowych zostały obliczone według pierwszego i trzeciego kwartyla. Dla dzieci w wieku 3 lat jest to 100 sekund kątowych, dla dzieci w wieku 4, 5, 6 lat - 70-100 sekund kątowych, a dla dzieci w wieku 7 lat $-50-70$ sekund katowych.

We would like to add the stereoscopic vision test to the basic screening for vision disorders among preschool children. We present the results of our study showing the child's testability by means of the Randot stereotest and media of stereoscopic vision levels in each age group between 3-7 years old.

Our study provides higher testability $(>97.2 \%)$ using the Randot stereotest among the children who underwent the examination compared with other studies regarding the Randot dot test examination, especially in 3 -year-old children $[8,9,10]$.
According to our study, we suggest implementing stereoscopic vision tests to the screening examination in the 4th year of life. Theoretically it is possible to detect stereopsis already in the $3 \mathrm{rd}$ month of life, but clinically it is possible only in 3rd-4th year of life. The lack of stereopsis in the Random Dot E test or Titmus stereotest suggests the presence of either strabismus or amblyopia and further comprehensive ophthalmological examinations should be provided [11].

The U.S. Preventive Services Task Force recommends screening to detect amblyopia, strabismus and defects in visual acuity in children younger than 5 years old [12]. Treatment of strabismus and amblyopia can improve visual acuity and reduce long-term amblyopia.

Normative data on the levels of stereoacuity in preschool children obtained in the current study are similar to findings in other studies regarding examination with random dot tests in preschool children $[1,3,13]$.

The current study demonstrates that there is a correlation between the level of stereopsis and the child's age. The stereopsis level increases with age statistically significantly (Fig. 1). The largest difference in the levels of stereopsis is marked between the age groups of 3,4,5-year-old and 6,7-year-old children. The older children have statistically significantly better results of stereoacuity than the younger ones. It means that the main developmental period of stereopsis begins at the age of 4 or 5 years old. This conclusion shows that it is crucial to perform a screening vision examination before the 4th year of life to be able to start vision therapy early enough. It is beneficial for the child's further life to avoid the severe consequences of undetected vision disorders. Detecting amblyopia in a 3, 4, 5-years-old child, when the plasticity of the brain is still significant, will allow proper correction of visual system impairments, which can lead to normal development of the visual system in the future.

Proven by the fact that the stereopsis level increases with age, not only the lack of stereopsis should be an indication for further ophthalmological investigation, but also stereoacuity findings lower than the mean values for each age group. There is a significantly decreased likelihood that a child with a severe visual disorder would attain a mean value of stereopsis in each age group [1]. 
The current findings are that among the children in whom stereopsis was not found, $100 \%$ of the ophthalmologically tested children had a vision defect and amblyopia. This fact proves the hypothesis about the importance of early stereoacuity examination in the detection of visual impairments in young children. The Randot stereotest is an effective tool in detecting the presence of stereoscopic vision already in children aged 3 . It is easy to conduct by any specialist, not only an ophthalmologist, which makes it an adequate screening examination. It is a valuable alternative method to detect visual impairments among 3-year-old children, when other methods are not easy enough to apply as a screening. It is known that while basic visual acuity testing, i.e. the Snellen chart, is more efficient among older children, it is hardly applicable in those younger ones.

The purpose of vision screening is to detect progressive, serious pediatric eye disorders, and particularly amblyopia, in a cost effective manner and at an early enough age for treatment to be effective. In Poland obligatory screening examinations regulated by the National Health Fund (NFZ) are administered by pediatricians in children aged 2 and later 4 years old and, concerning the visual system, it only contains tests detecting strabismus. Our goal is to implement the Randot stereotest examination in the 4-year-old child's obligatory pediatric screening examination based on the previously explained visual system development features. Based on this study, we can provide normative values for stereoacuity levels in preschool children that may be applicable to clinical testing.

\section{CONCLUSIONS}

The Randot stereotest turned out to be an effective tool in detecting binocular vision disorders in preschool children. The authors suggest implementing the Randot stereotest to complement screening program to detect amblyopia in preschool aged children.

\author{
Author's contribution \\ Study design - D. Pojda-Wilczek, A.Muskalska, E. Chlasta-Twardzik, B. Sędziak-Marcinek, M. Krok \\ Data collection - A. Muskalska, E. Chlasta-Twardzik, B. Sędziak-Marcinek, M. Krok \\ Data interpretation - A. Muskalska, E. Chlasta-Twardzik, B. Sędziak-Marcinek, M. Krok, D. Pojda-Wilczek \\ Statistical analysis - A. Muskalska, E. Chlasta-Twardzik, B. Sędziak-Marcinek, M. Krok \\ Manuscript preparation - A. Muskalska, E. Chlasta-Twardzik, B. Sędziak-Marcinek, M. Krok, D.Pojda-Wilczek \\ Literature research - A. Muskalska, E. Chlasta-Twardzik, B. Sędziak-Marcinek, M. Krok
}

\title{
PIŚMIENNICTWO
}

1. Ciner E.B., Ying G., Kulp M.T., Maguire M.G., Quinn G.E., Orel-Bixler D., Cyert L.A., Moore B., Huang J. Stereoacuity of Preschool Children with an without Vision Disorders. Optom. Vis. Sci. 2014; 91(3): 351-358, doi: 10.1097/ OPX.0000000000000165.

2. Schmidt P.P., Maguire M.G., Moore B., Cyert L. Testability of preschoolers on stereotests used to screen vision disorders. Optom. Vis. Sci. 2003; 80(11): 753-757, doi: 10.1097/00006324-200311000-00012

3. Afsari S., Rose K.A., Pai A.S., Gole G.A., Leone J.F., Burlutsky G., Mitchell P. Diagnostic reliability and normative values of stereoacuity tests in preschoolaged children. Br. J. Ophthalmol. 2013; 97(3): 308-313, doi: 10.1136/bjophthalmol-2012-302192.

4. Nelson H., Nygren P., Huffman L., Wheeler D., Hamilton A. Screening for visual impairment in children younger than Age 5 years: update of the evidence from randomized controlled trials, 1999-2003. Agency for Healthcare Research and Quality, Rockville, MD. 2004, doi: 10.1370/afm.193

5. Thompson J.R., Woodruff G., Hiscox F.A., Strong N., Minshull C. The incidence and prevalence of amblyopia detected in childhood. Public Health, 1991; 105(6): 455-462, doi: 10.1016/S0033-3506(05)80616-X

6. Packwood E.A., Cruz O.A., Rychwalski P.J., Keech R.V. The psychosocial effects of amblyopia study. JAAPOS 1999; 3(1): 15-17, doi: 10.1016/S1091 8531(99)70089-3

7. Chua B., Mitchell P. Consequences of amblyopia on education, occupation, and long term vision loss. Br. J. Ophthalmol. 2004; 88(9): 1119-1121, doi: 10.1136/bjo.2004.041863.

8. Krueger D.E., Ederer F. Report on the National Eye Institute's Visual Acuity Impairment Survey Pilot Study. Office of Biometry and Epidemiology. National Institutes of Health, Public Health Services. Department of Health and Human Services Bethesda 1984.

9. Tomaç S., Altay Y. Near stereoacuity: development in preschool children; normative values and screening for binocular vision abnormalities, a study of 115 children. Binocul. Vis. Strabismus Q. 2000; 15(3): 221-228. PMID: 10960225.

10. Tarczy-Hornoch K., Lin J., Deneen J., Cotter S.A., Azen S.P., Borchert M.S., Wang Y., Varma R. Stereoacuity testability in African-American and Hispanic preschool children. Optom. Vis. Sci. 2008; 85(3): 158-163, doi: 10.1097/OPX.0b013e3181643ea7.

11. Trager M.J., Dirani M., Fan Q., Gazzard G., Selvaraj P., Chia A., Wong T.Y., Young T.L., Varma R., Saw S.M. Testability of vision and refraction in preschoolers: the strabismus, amblyopia, and refractive error study in Singaporean children. Am. J. Ophthalmol. 2009; 148(2): 235-241, doi: 10.1016/j. ajo.2009.02.037

12. Riordan-Eva P., Whitcher J.P. Specjalne zagadnienia z zakresu okulistyki dziecięcej. W: Okulistyka Vaughana i Ausbury’ego. Red. E. Wylęgała. Czelej, Lublin 2011; s. 355.

13. Screening for Visual Impairment in Children Younger Than Age 5 Years: Recommendation Statement. Ann. Fam. Med. 2004; 2(3): 263-266. 